\title{
Carbon and mineral nutrient pools in a gallery forest at Mogi Guaçu River, Southeast Brazil
}

\author{
Welington B.C. Delittia,b,* and Déborah M. Burger ${ }^{\mathrm{a}}$ \\ ${ }^{a}$ Departamento de Ecologia Geral, Instituto de Biociências, Universidade de São Paulo, \\ Caixa Postal 11461 CEP 05422-970, São Paulo, SP, Brazil \\ ${ }^{\mathrm{b}}$ CEAM, Centro de Estudios Ambientales del Mediterráneo, Parque Tecnológico,C/ 4, Sector Oeste, \\ 46980 Paterna (Valencia), Spain
}

(Received 25 February 1999; accepted 15 May 1999)

\begin{abstract}
The objective of this study is to quantify the concentration and total amount of nutrients stored in a gallery forest ecosystem. The study was carried out in a forest along the Mogi Guaçu River, Itapira, S.P., Southeast Brazil. Aboveground plant biomass and nutrient content were measured by the destructive method and the soil analysed for nutrient content. In the plant biomass, leaves showed the greatest nutrient concentrations, but stems comprised the major nutrient pools due to their greater biomass $(95 \%$ of the total). Trees stored the greatest part of the forest aboveground nutrients, as they represent $88 \%$ of the total vegetation biomass. More nutrients were present in the soil than in the vegetation, due to the soil greater mass. The mean cycling times in this type of ecosystem were calculated as the ratio between the pools and the fluxes of each nutrient. Results were compared with other tropical ecosystems.
\end{abstract}

carbon / gallery forest / mineralmass / nutrient concentration / nutrient pools / soil carbon / soil nutrients

Résumé - Carbone et stock d'éléments minéraux dans une forêt galerie de la rivière Mogi Guaçu, au Sud Est du Brésil. L'objectif de cette étude est de quantifier la concentration et le contenu total d'éléments minéraux accumulés dans un écosystème de forêt galerie. L'étude s'est développée dans une bande de forêt le long de la rive de la rivière Mogi Guaçu, Itapira, dans l'État de Sao Paolo, au Sud Est du Brésil. La biomasse végétale aérienne a été mesurée selon la méthode destructive, et le contenu d'éléments minéraux dans le sol a été analysé. Les feuilles ont montré qu'il y avait la plus grande concentration d'éléments minéraux dans la biomasse végétale, mais les tiges ont contribué au pool le plus important d'éléments minéraux dû à sa majeure biomasse $(95 \%$ du total). Les arbres accumulent la plus grande partie du total d'éléments minéraux de la forêt étant donné qu'ils représentent $88 \%$ de la biomasse végétale totale. L'accumulation de l'ensemble d'éléments est plus grande au sol que dans la végétation dû à une plus grande masse du sol. Le rapport entre les données de retombée de litière et les stocks d'éléments minéraux a été utilisé dans le but d'estimer les temps moyens des cycles d'éléments biogènes dans ce type d'écosystème. Les résultats sont comparés avec d'autres écosystèmes tropicaux.

carbone / nutriments / cycles d'éléments minéraux / mineralomasse / forêt galerie / forêt tropicaux

\section{INTRODUCTION}

Gallery forests play an important ecological function controlling water and nutrient flows from terrestrial to aquatic ecosystems. In the domain of the Brazilian savannahs (Cerrados), gallery forests are established in strips along the rivers and their development depends on the superior water supply maintained by these 
rivers, even during the seasonal dry periods. Moreover, the presence of a river enhances the soil site characteristics through flooding and sedimentation. Most water flowing to the rivers passes through the gallery forests where a large part of the sediments and nutrients are retained by the vegetation $[17,27,38]$. Runoff water slow down through the forest and sediments in the forest floor. Plants absorb the dissolved nutrients from the flowing water and, subsequently, soil properties are changed by nutrient and organic matter addition, via litterfall and decomposition [17]. These processes allow moister and nutrient-richer forests to develop in this region where the acidic, low fertility soil and the deeper water table favour the presence of tropical seasonal savannahs. Neighbouring aquatic and terrestrial ecosystems are both influenced by the filtering action of these forests, and the nutrient dynamics in such forests is especially important for the stability of the landscape [17, 38].

In many tropical regions, gallery forests represent extensions of moist forest flora into drier or seasonally dry regions. In Brazil these forests may present species from other floristic provinces, and they function as corridors between them. Gallery forests have their own species, and they also share some species with other neighbouring ecosystems, such as woody savannahs and mesophilous forests. Many animal species also depend on gallery forests as sources of food, nesting sites, refuge and migration routes. All these characteristics emphasise the high conservation value and the importance of landscape diversity in these systems.

Despite their importance, there are few data on these types of forest in tropical regions. This lack of information was emphasised in a recent international meeting devoted to tropical gallery forests [29]. Gallery and all tropical forests are under heavy human pressure, and management programs need a better ecological database if sustainable development is to be reached. Moist tropical forests have been much more thoroughly studied than gallery forests and forests in dry zones, despite the fact that all of them are important ecosystems and play key roles in biosphere stability [38].

Physiognomic, floristic and biomass surveys [7, 36, 39] clearly distinguish gallery forests from the surrounding savannahs. However, we do not know how different the storage and dynamics of nutrients are in such forests, nor, specifically, how the better water supply in this area modifies the potential biomass and nutrient dynamics.

Some general patterns are recognised in the nutrient dynamics of tropical forests, such as low soil fertility and the storage of most nutrients in biomass. They also present rapid cycling of small amounts of nutrients via litterfall and decomposition [5, 28, 31, 47, 50]. For Brazil and other tropical regions there are some studies on the structure and restoration of gallery forest plant communities, but very few on nutrient cycling [1, 13, 29]. Recent studies have focused on leaf nutrient concentration [43] and on the relationship between soil properties and plant communities in Central Brazil [26, 51]. But there are no data on nutrient storage in the biomass and soils of gallery forests in Brazil; this is probably due to the problems related to direct forest biomass evaluations. Destructive methods are time-consuming and the need for conservation of the remaining tropical forests limits this type of research [38].

The objective of this study is to evaluate nutrient storage in some compartments of a gallery forest in the Southeast region of Brazil, and to compare these results with data from the adjacent, predominantly savannah ecosystem and from other tropical forests.

\section{MATERIAL AND METHODS}

\subsection{Study area}

This study was carried out in a strip (50 to $200 \mathrm{~m}$ wide) of gallery forest adjoining the Mogi Guaçu River, municipality of Itapira, State of São Paulo, Southeast Brazil $\left(22^{\circ} 21^{\prime} \mathrm{S}, 46^{\circ} 51^{\prime} \mathrm{W}\right)$. The forest was included in the area to be flooded by the River Mogi Guaçu Dam [9], and this fact was an important reason for choosing this study site, as recommended in literature [38].

The regional climate is tropical, type II, [55], with rainy summers and seasonal winter droughts. Mean annual $(n=21)$ temperature and rainfall were $20.8^{\circ} \mathrm{C}$ and $1359 \mathrm{~mm}$, respectively [6, 15]. Soil type in the savannah region is classified as Red-yellow latosol (Oxisol), and the influence of water is important for forest establishment because the adjacent river maintain a better water supply year round and changes the soil properties [44].

The ecosystem was classified as a Semi-deciduous mesophilous gallery forest [36]. Diversity was low, and Inga uruguensis (Mimosoideae) was the dominant species. Other important families were Lauraceae, Euphorbiaceae, Meliaceae, Myrtaceae, Melastomataceae and Meliaceae. Density was 4120 trees $\mathrm{ha}^{-1}$, and the maximum tree height was $15 \mathrm{~m}$, while mean stem diameter was $9.6 \pm 1.8 \mathrm{~cm}$. Herbs were rare and lianas very abundant (Bignoniaceae, Sapindaceae and Convolvulaceae).

The original vegetation prevailing in the region was the savannah (Campos Cerrados) with this type of gallery forests along the rivers. On richer soils semidecidous forests also occurred. Nowadays all savannahs 
and forests are rare due to changes caused by human activities. In the State of São Paulo more than $80 \%$ of the original ecosystem territory has been changed to agrosystems.

\section{METHODS}

Aboveground biomass was measured in 12 plots $(5 \times$ $5 \mathrm{~m}$ ) by the destructive method. In each plot, the herbs and lianas were cut to ground level in 3 sub-plots of $3 \mathrm{~m}^{2}$, and the leaves and stems were sorted. The whole litter layer was also collected in the same sub-plots.

All the trees were cut down in 7 of the 12 plots, and leaves and stems were separated. In these plots a total of 92 trees were cut down; they were representative of the total range of heights and diameters observed in this forest during the field survey. This tree sample was sufficient for biomass evaluation, with minimum habitat destruction, as is recommended nowadays [38]. The total forest biomass amounted to $133.3 \mathrm{Mg} \mathrm{ha}^{-1} ; 88 \%$ of this was comprised of trees. $95 \%$ of the total site biomass was composed by of stems. From the same sampling the authors selected the best equation for tree biomass in this forest:

$$
\begin{gathered}
\text { Total Dry Weight }=[0.523+0.053 \text { perimeter }]^{3} \\
R^{2}=0.94 P<0.001 .
\end{gathered}
$$

Biomass determination is developed in Burger [6] and Burger and Delitti [7].

All plant materials were weighed fresh and samples were taken to the laboratory, where they were oven-dried to constant weight and their mass determined. By this procedure the dry weight per unit area was obtained for plant leaves and stems and for the litter layer.

All the samples were ground in a Willey mill and three subsamples from each plant fraction per plot were sent for chemical analysis. Total concentrations of N, P, $\mathrm{K}, \mathrm{Ca}, \mathrm{Mg}, \mathrm{S}, \mathrm{Fe}, \mathrm{Cu}, \mathrm{B}, \mathrm{Zn}$ and $\mathrm{Mn}$ in plant materials were determined at the laboratories of the Center of Nuclear Energy for Agriculture (CENA), at the University of São Paulo [58]. The methods used were: Emission Spectrometry (Induced argon plasma) for $\mathrm{P}$, $\mathrm{Ca}, \mathrm{Mg}, \mathrm{Fe}, \mathrm{Cu}, \mathrm{Mn}, \mathrm{B}$ and $\mathrm{Zn}$ [33]; Colorimetry for Total $N$ [33]; Atomic absorption for $K$ [57] and Turbidimetry for $S$ [34]. The accuracy of the results was confirmed by comparison with standard pine leaves (NIST 1575) and apple leaves (NIST 1515).

Mass of minerals per unit of area was calculated from the biomass data $\left(\mathrm{kg} \mathrm{ha}^{-1}\right)$ and mean nutrient concentration.
Soil samples were taken from 3 profiles on each of the 12 plots. The soil profiles presented three layers recognisable by colour and texture, with the following mean depth: A) $0-10 \mathrm{~cm}$ (dark-brown), B) $10-60 \mathrm{~cm}$ (brown) and C) 60-100 cm (grey-brown). At each point the soil was excavated to a depth of $1 \mathrm{~m}$ and one soil sample (volume $=1$ liter) was taken from each layer. The total number of samples was 108; means were calculated per plot and, afterwards, for the total forest.

Soil samples were air dried and sieved through a $2 \mathrm{~mm}$ mesh and sent for available nutrient analysis at the soil fertility laboratory of CENA, USP. The micronutrients were analysed by the DTPA method [37]. Extractable $P\left(\mathrm{PO}_{4}{ }^{3}\right)$ and $K$ were determined by colorimeter and flame photometer, respectively, $S$ - precipitated as bariun sulphate - by gravimetry and exchangeable $\mathrm{Ca}$ and $\mathrm{Mg}$ by titration, with three replicates per determination (total 324 per nutrient). The methods are fully described in literature $[18,48]$.

Texture and soil densities were determined at the Department of Soil Science, Faculty of Agronomy, University of São Paulo. Texture (pipette method) and density measures were carried out in 3 replicates per soil layer from each sampling point (total 108).

Total nutrient pools were calculated using soil layer thickness, densities and nutrient concentration and averaged for each plot $(n=3)$; then these values were averaged for the whole site $(n=12)$.

The nutrient pool values obtained were related to the nutrient fluxes carried by total litterfall data observed in a similar forest from the same watershed [14]. Nutrient mean cycling time (yr) was calculated as the relation between nutrient pool $\left(\mathrm{kg} \mathrm{ha}^{-1}\right)$ and nutrient flow $(\mathrm{kg}$ $\mathrm{ha}^{-1} \mathrm{yr}^{-1}$ ) [49].

In this way, we evaluated some nutrient cycling parameters for this type of ecosystem and compared the nutrient dynamics in each compartment.

\section{RESULTS}

The mean nutrient concentrations for each compartment of plant biomass are presented in table I. The following general pattern of decreasing concentrations was observed: $N>\mathrm{Ca} \cong K>\mathrm{Mg}>S$ and $P$, for macronutrients, and $\mathrm{Fe}>\mathrm{Mn}>\mathrm{Zn}>\mathrm{B}>\mathrm{Cu}$, for micronutrients.

Table II presents the amount of stored nutrients in plant biomass. Of the macronutrients, nitrogen was the most accumulated nutrient after carbon, while the smallest amounts were sulphur and phosphorus. Iron and manganese were the micronutrients present in greatest amounts, and copper showed the lowest values. 
Table I. Nutrient concentrations in gallery forest compartments, Itapira, SP, Brazil. Values are mean (s.d.), $n=12$.

\begin{tabular}{|c|c|c|c|c|c|c|c|c|}
\hline \multirow{2}{*}{\multicolumn{2}{|c|}{ Nutrients }} & \multicolumn{2}{|c|}{ Trees } & \multicolumn{2}{|c|}{ Herbs } & \multicolumn{2}{|c|}{ Lianes } & \multirow{3}{*}{$\begin{array}{c}\text { Litter } \\
38.2(5.2)\end{array}$} \\
\hline & & \multirow{2}{*}{$\begin{array}{c}\text { Leaves } \\
50.0(5.8)\end{array}$} & \multirow{2}{*}{$\begin{array}{c}\text { Stems } \\
48.6(9.5)\end{array}$} & \multirow{2}{*}{$\begin{array}{c}\text { Leaves } \\
39.7(4.4)\end{array}$} & \multirow{2}{*}{$\begin{array}{c}\text { Stems } \\
46.3(15.0)\end{array}$} & \multirow{2}{*}{$\begin{array}{c}\text { Leaves } \\
44.1(3.5)\end{array}$} & \multirow{2}{*}{$\frac{\text { Stems }}{46.6(4.5)}$} & \\
\hline C & $\%$ & & & & & & & \\
\hline$N$ & $\mathrm{mg} \mathrm{g}^{-1}$ & $31.0(1.8)$ & $4.8(0.9)$ & $30.4(3.0)$ & $9.1(1.5)$ & $32.3(3.5)$ & $14.0(2.7)$ & $18.6(1.3)$ \\
\hline$C / N$ & & $16.1(0.9)$ & $107.2(18.9)$ & $13.3(1.2)$ & $51.9(7.4)$ & $13.5(1.2)$ & $32.9(6.1)$ & $20.8(1.4)$ \\
\hline$P$ & $\mathrm{mg} \mathrm{g}^{-1}$ & $2.3(0.2)$ & $0.6(0.3)$ & $1.9(0.1)$ & $1.0(0.1)$ & $2.1(0.2)$ & $1.4(0.2)$ & $1.0(0.1)$ \\
\hline$K$ & $\mathrm{mg} \mathrm{g}^{-1}$ & $10.7(1.7)$ & $3.1(0.8)$ & $12.4(1.6)$ & $6.2(1.8)$ & $15.1(1.7)$ & $8.0(0.7)$ & $3.7(0.6)$ \\
\hline $\mathrm{Ca}$ & $\mathrm{mg} \mathrm{g}^{-1}$ & $8.4(2.2)$ & $3.6(0.8)$ & 10.5 (1.9) & $5.9(1.1)$ & $16.3(3.7)$ & 7.4 (1.9) & $14.8(2.3)$ \\
\hline $\mathrm{Mg}$ & $\mathrm{mg} \mathrm{g}^{-1}$ & $3.4(0.9)$ & $0.7(0.2)$ & $4.8(0.8)$ & $1.4(0.4)$ & $4.5(0.9)$ & $1.7(0.3)$ & $3.4(0.4)$ \\
\hline$S$ & $\mathrm{mg} \mathrm{g}^{-1}$ & $2.0(0.3)$ & $0.6(0.3)$ & $3.0(0.3)$ & $1.4(0.2)$ & $2.1(0.1)$ & $1.1(0.2)$ & $1.8(0.2)$ \\
\hline $\mathrm{Fe}$ & $\mathrm{mg} \mathrm{kg}^{-1}$ & $464.4(70.9)$ & $119.0(91.8)$ & $5298.1(1657.1)$ & $1057.8(312.5)$ & $589.1(276.1)$ & $157.6(118.3)$ & $5412.6(2013.7)$ \\
\hline $\mathrm{Cu}$ & $\mathrm{mg} \mathrm{kg}^{-1}$ & $14.3(2.6)$ & $5.0(0.2)$ & $14.8(2.3)$ & $7.9(2.3)$ & $9.8(0.9)$ & $8.5(0.7)$ & $17.9(20.6)$ \\
\hline $\mathrm{Mn}$ & $\mathrm{mg} \mathrm{kg}^{-1}$ & $356.2(54.1)$ & $81.3(52.9)$ & $710.2(172.0)$ & $315.5(114.6)$ & $2330.5(565.8)$ & $562.6(200.9)$ & $1133.7(268.9)$ \\
\hline $\mathrm{Zn}$ & $\mathrm{mg} \mathrm{kg}^{-1}$ & $31.5(2.9)$ & $7.1(5.6)$ & $42.4(3.0)$ & $167.0(453.2)$ & $33.4(7.2)$ & $43.1(11.0)$ & $50.4(7.7)$ \\
\hline B & $\mathrm{mg} \mathrm{kg}^{-1}$ & $21.3(1.9)$ & $10.7(0.9)$ & $30.5(6.0)$ & $10.2(0.9)$ & $32.3(4.7)$ & $10.7(1.0)$ & $15.7(3.9)$ \\
\hline
\end{tabular}

Table II. Biomass and litter layer nutrient pools in the gallery forest, Itapira, SP, Brazil.

\begin{tabular}{|c|c|c|c|c|c|c|c|c|}
\hline & & \multicolumn{2}{|c|}{ Trees } & \multicolumn{2}{|c|}{ Herbs } & \multicolumn{2}{|c|}{ Lianas } & \multirow[t]{2}{*}{ Litter } \\
\hline & & Leaves & Stems & Leaves & Stems & Leaves & Stems & \\
\hline Biomass* & $\mathrm{kg} \mathrm{ha}^{-1}$ & 3700 & 114300 & 100 & 200 & 3500 & 11600 & 3240 \\
\hline$C$ & $\mathrm{~kg} \mathrm{ha}^{-1}$ & 1840.0 & 55540.1 & 27.8 & 101.9 & 1521.5 & 5400.9 & 1237.7 \\
\hline$N$ & $\mathrm{~kg} \mathrm{ha}^{-1}$ & 114.7 & 548.5 & 2.1 & 2.0 & 111.4 & 162.3 & 60.3 \\
\hline$P$ & $\mathrm{~kg} \mathrm{ha}^{-1}$ & 8.5 & 68.6 & 0.1 & 0.2 & 7.3 & 16.2 & 3.2 \\
\hline$K$ & $\mathrm{~kg} \mathrm{ha}^{-1}$ & 39.4 & 354.3 & 0.9 & 1.4 & 52.1 & 92.7 & 11.9 \\
\hline $\mathrm{Ca}$ & $\mathrm{kg} \mathrm{ha}^{-1}$ & 30.9 & 411.4 & 0.7 & 1.3 & 56.2 & 85.8 & 47.9 \\
\hline $\mathrm{Mg}$ & $\mathrm{kg} \mathrm{ha}^{-1}$ & 12.5 & 80.0 & 0.4 & 0.3 & 15.5 & 19.7 & 11.0 \\
\hline S & $\mathrm{kg} \mathrm{ha}^{-1}$ & 7.4 & 45.7 & 0.2 & 0.3 & 7.3 & 12.8 & 5.8 \\
\hline $\mathrm{Fe}$ & $\mathrm{g} \mathrm{ha}^{-1}$ & 1709.1 & 13599.3 & 370.9 & 232.7 & 2032.4 & 1826.8 & $\begin{array}{c}5.0 \\
17536.7\end{array}$ \\
\hline $\mathrm{Cu}$ & $\mathrm{g} \mathrm{ha}^{-1}$ & 52.6 & 580.5 & 1.0 & 1.6 & 33.8 & 98.8 & 57.8 \\
\hline $\mathrm{Mn}$ & $\mathrm{g} \mathrm{ha}^{-1}$ & 1310.8 & 9287.5 & 49.1 & 69.4 & 8040.5 & 6520.2 & 3673.1 \\
\hline $\mathrm{Zn}$ & $\mathrm{g} \mathrm{ha}^{-1}$ & 112.3 & 821.7 & 2.9 & 36.7 & 115.2 & 499.9 & 163.2 \\
\hline B & $\mathrm{g} \mathrm{ha}^{-1}$ & 78.5 & 1142.8 & 2.1 & 2.2 & 111.4 & 124.5 & 50.8 \\
\hline
\end{tabular}

* From $(6,7)$.

The soil textural class is clay (clay $=54.1 \pm 2.8 \%$; silt $=39.9 \pm 2.9 \%$ and sand $=6 \pm 3 \%)$ and a high cation exchange capacity (CEC) is expected because of the elevated clay content. Particle and bulk soil densities were $2.3 \pm 0.1$ and $1.0 \pm 0.1$, respectively, which are in the range of values commonly found for this type of soil.

The soil nutrient concentration decreased from the surface to the deeper layers (table III), but the second layer $(\cong 10-60 \mathrm{~cm})$ comprised the major nutrient reservoir due to its greater volume and mass (table IV). The distribution of nutrients in the different compartments showed that soil is the main reservoir in this forest (table V).

Mean cycling times (years) differ between compartments and also vary according to each nutrient. Stems presented the major aboveground nutrient pools and the slowest cycle of all the elements (table VI).

\section{DISCUSSION}

In the plants and in the litter layer, the ratio of nutrient concentrations $(N>\mathrm{Ca}>K>\mathrm{Mg}>S>P)$ was very similar to that obtained in the different fractions of plant biomass and was the same as in other forests in the same region $[8,41]$. Differences found in nutrient concentrations and nutrient storage among ecosystems are due to differences in soil type, floristic composition, climate, and water dynamics, the latter being especially important in gallery forests, because of the periodic floods $[10,16$, 19, 20]. 
Table III. Organic matter and nutrient concentrations in the gallery forest soil, according to profile layers (Itapira, SP, Brazil). Values are mean (s.d.), $n=12$.

\begin{tabular}{|c|c|c|c|c|c|}
\hline \multirow[b]{2}{*}{ O.M. } & \multirow[b]{2}{*}{$\left(\mathrm{g} \mathrm{kg}^{-1}\right)$} & \multicolumn{2}{|c|}{$\begin{array}{l}\text { Upper layer } \\
(0-10 \mathrm{~cm})\end{array}$} & $\begin{array}{l}\text { Middle layer } \\
(11-60 \mathrm{~cm})\end{array}$ & $\begin{array}{l}\text { Lower layer } \\
(61-100 \mathrm{~cm})\end{array}$ \\
\hline & & 34.95 & $(7.70)$ & $19.12(4.57)$ & $11.18 \quad(2.22)$ \\
\hline $\mathrm{P}$ & $\left(\mathrm{mg} \mathrm{kg}^{-1}\right)$ & 20.72 & $(6.43)$ & $10.36(3.24)$ & 5.89 \\
\hline $\mathrm{K}$ & $(\mathrm{mmol} \mathrm{kg}-1)$ & 3.00 & (1.86) & $1.06(0.78)$ & $0.42 \quad(0.16)$ \\
\hline $\mathrm{Ca}$ & $\left(\mathrm{mmol} \mathrm{kg}^{-1}\right)$ & 29.81 & $(17.79)$ & $8.34 \quad(5.40)$ & $2.21 \quad(1.12)$ \\
\hline $\mathrm{Mg}$ & $\left(\mathrm{mmol} \mathrm{kg} \mathrm{kg}^{-1}\right)$ & 9.45 & $(5.06)$ & $2.86(1.82)$ & $0.76(0.52)$ \\
\hline $\mathrm{Al}+\mathrm{H}$ & $\left(\mathrm{mmol} \mathrm{kg}{ }^{-3}\right)$ & 67.65 & (15.06) & 84.82 (13.31) & 80.82 (16.64) \\
\hline $\mathrm{S}$ & $\left(\mathrm{mg} \mathrm{kg}^{-1}\right)$ & 9.05 & $(2.69)$ & $6.97(1.46)$ & 7.27 \\
\hline $\mathrm{Fe}$ & $\left(\mathrm{mg} \mathrm{kg}^{-1}\right)$ & 222.10 & $(39.91)$ & $134.30 \quad(25.32)$ & $110.28(25.32)$ \\
\hline $\mathrm{Cu}$ & $\left(\mathrm{mg} \mathrm{kg}^{-1}\right)$ & 2.42 & $(0.24)$ & $2.02(0.41)$ & $1.07(0.26)$ \\
\hline $\mathrm{Mn}$ & $\left(\mathrm{mg} \mathrm{kg}^{-1}\right)$ & 83.32 & $(28.23)$ & $62.38(22.57)$ & $13.77(8.69)$ \\
\hline $\mathrm{Zn}$ & $\left(\mathrm{mg} \mathrm{kg}^{-1}\right)$ & 3.88 & (1.14) & $2.13(0.79)$ & $0.72(0.17)$ \\
\hline $\mathrm{pH}$ & & 4.48 & $(0.30)$ & $4.15 \quad(0.15)$ & $4.06(0.10)$ \\
\hline
\end{tabular}

Table IV. Soil organic matter and nutrient pools in the gallery forest soil, Itapira, SP, Brazil. Values are mean (s.d.), $n=12$.

\begin{tabular}{|c|c|c|c|c|c|c|c|c|c|}
\hline \multirow[b]{2}{*}{ O.M. } & \multirow[b]{2}{*}{$\left(\mathrm{Mg} \mathrm{ha}^{-1}\right)$} & \multicolumn{2}{|c|}{$\begin{array}{l}\text { Upper layer } \\
(0-10 \mathrm{~cm})\end{array}$} & \multicolumn{2}{|c|}{$\begin{array}{l}\text { Middle layer } \\
(11-60 \mathrm{~cm})\end{array}$} & \multicolumn{2}{|c|}{$\begin{array}{l}\text { Lower layer } \\
(61-100 \mathrm{~cm})\end{array}$} & \multicolumn{2}{|c|}{$\begin{array}{c}\text { Total } \\
(0-100 \mathrm{~cm})\end{array}$} \\
\hline & & 34.00 & (5.6) & 106.33 & (9.35) & 50.46 & (7.92) & 190.82 & (17.94) \\
\hline $\mathrm{P}$ & $\left(\mathrm{kg} \mathrm{ha}^{-1}\right)$ & 19.70 & (4.6) & 54.66 & (5.69) & 23.15 & (2.85) & 97.52 & (6.96) \\
\hline K & $\left(\mathrm{kg} \mathrm{ha}^{-1}\right)$ & 100.40 & (38.6) & 206.74 & (72.34) & 59.81 & (7.01) & 366.91 & (101.57) \\
\hline $\mathrm{Ca}$ & $\left(\mathrm{kg} \mathrm{ha}^{-1}\right)$ & 1261.40 & (520.4) & 1804.34 & $(548.27)$ & 312.77 & (73.04) & 3378.52 & (942.52) \\
\hline $\mathrm{Mg}$ & $\left(\mathrm{kg} \mathrm{ha}^{-1}\right)$ & 240.00 & (95.1) & 374.38 & (125.24) & 58.16 & (10.15) & 672.58 & (191.83) \\
\hline$S$ & $\left(\mathrm{~kg} \mathrm{ha}^{-1}\right)$ & 9.55 & $(1.78)$ & 39.56 & $(6.25)$ & 34.74 & $(5.8)$ & 83.84 & $(12.72)$ \\
\hline $\mathrm{Fe}$ & $\left(\mathrm{kg} \mathrm{ha}^{-1}\right)$ & 211.35 & (22.74) & 753.32 & (64.14) & 501.70 & (57.11) & 1466.37 & (109.40) \\
\hline $\mathrm{Cu}$ & $\left(\mathrm{kg} \mathrm{ha}^{-1}\right)$ & 2.44 & $(0.24)$ & 11.42 & $(0.95)$ & 4.60 & $(0.54)$ & 18.49 & (1.07) \\
\hline $\mathrm{Mn}$ & $\left(\mathrm{kg} \mathrm{ha}^{-1}\right)$ & 91.20 & (10.05) & 346.07 & (59.87) & 49.89 & $(9.49)$ & 487.16 & (67.99) \\
\hline $\mathrm{Zn}$ & $\left(\mathrm{kg} \mathrm{ha}^{-1}\right)$ & 3.90 & $(0.67)$ & 12.34 & (2.06) & 3.17 & $(0.40)$ & 19.41 & $(2.51)$ \\
\hline
\end{tabular}

Table V. Total nutrient pool distribution in the gallery forest, Itapira, SP, Brazil.

\begin{tabular}{lcccccc}
\hline & \multicolumn{2}{c}{ Biomass } & \multicolumn{2}{c}{ Soil } & \multicolumn{2}{c}{$\begin{array}{c}\text { Litter } \\
\end{array}$} \\
$\mathrm{kg} \mathrm{ha}^{-1}$ & $\%$ & $\mathrm{~kg} \mathrm{ha}^{-1}$ & $\%$ & $\mathrm{~kg} \mathrm{ha}^{-1}$ & $\%$ \\
\hline $\mathrm{C}$ & 64432.2 & 36.5 & 110684.5 & 62.8 & 1237.7 & 0.7 \\
$\mathrm{P}$ & 100.9 & 50.0 & 97.5 & 48.4 & 3.2 & 1.6 \\
$\mathrm{~K}$ & 540.8 & 58.8 & 366.9 & 39.9 & 11.9 & 1.3 \\
$\mathrm{Ca}$ & 586.3 & 14.6 & 3378.5 & 84.2 & 47.9 & 1.2 \\
$\mathrm{Mg}$ & 128.4 & 15.8 & 672.6 & 82.8 & 11 & 1.4 \\
$\mathrm{~S}$ & 73.7 & 45.1 & 83.8 & 51.3 & 5.8 & 3.6 \\
$\mathrm{Fe}$ & 19.8 & 1.3 & 1466.4 & 97.5 & 17.54 & 1.2 \\
$\mathrm{Cu}$ & 0.8 & 4.0 & 18.5 & 95.7 & 0.06 & 0.3 \\
$\mathrm{Mn}$ & 25.3 & 4.9 & 487.2 & 94.4 & 3.7 & 0.7 \\
$\mathrm{Zn}$ & 1.6 & 7.5 & 19.4 & 91.7 & 0.16 & 0.8 \\
\hline
\end{tabular}

Leaves have the highest nutrient concentration, while stems frequently have the lowest values. This is commonly observed in other ecosystems [22, 31, 46, 47].
Trees contained the greatest $\mathrm{C}$ concentrations and their greatest biomass influenced the overall mean. Other compartments with smaller C concentrations also showed smaller biomasses and so they store much lower $\mathrm{C}$ amounts (table I). Tree leaves contained greater $\mathrm{C}$ concentrations than stems, but in other plant compartments this was not observed.

The $C / N$ ratio clearly distinguished the leaves from the stems. Litter had $C / N$ values similar to the leaves, as leaves were the main component of that compartment. The litter from other plant parts is supposed to converge to lower $C / N$ ratio values during the decomposition processes, through faster $C$ than $N$ loss [54]. Moreover, a net import of $N$ from surrounding material to the litter may occur, carried by colonisation and the activity of the decomposing community. Through these processes, there is an increase in $N$ concentration and a decrease in the $C / N$ ratio during decomposition [52]. 
The vegetation studied presented great concentrations of manganese (table I) surpassing the limit of $300 \mathrm{mg}$ $\mathrm{kg}^{-1}$ suggested for Mn accumulators [43]. Mn critical toxicity content is highly variable among plant species and growing conditions, but the particularly high $\mathrm{Mn}$ values presented by the lianas are close to the maximum critical toxicity levels reported [40]. The herbs accumulated $\mathrm{Fe}$ above the toxicity limits stated for plants in general [40], while the trees showed the smallest concentrations of many elements among the three plant groups. Water logging in the soil may make Fe and Mn mobile and induce the observed accumulation of $\mathrm{Fe}$ and $\mathrm{Mn}$ [11]. The high concentrations of some elements (N, Fe and $\mathrm{Mn}$ ) may result from the filtering action of the forest for these elements.

The litter layer contained the smallest nutrient pools (table II), but it plays a very important role in ecosystem dynamics because it is the site of the main decomposition processes and the rapid turnover of nutrients.

Soil properties are very different from the soil type prevailing in the neighbouring areas (Oxisol), where sand is the main mineral fraction and the bulk density is higher [44]. The differences are attributed to the input of fine sediments by floods.

The amount of nutrients stored in the soil is greater in most cases than the values stored in the aboveground plant biomass (table $V$ ). A one-meter depth of soil weighs $10000 \mathrm{Mg} \mathrm{ha}^{-1}$, (bulk density = 1), while plant biomass was less than $134 \mathrm{Mg} \mathrm{ha}^{-1}$. Moreover, the higher clay and organic matter contents indicate a higher CEC in the gallery forest and provide suitable conditions for the forest to filter and retain the nutrients carried by water flow.

Stem and leaf compartments differed greatly with respect to the mean cycling time, which was much higher in stems than in leaves. There were also differences between the nutrient cycling times. $\mathrm{Mn}$ and $\mathrm{Cu}$ presented the slowest and the fastest cycles, respectively, in the stem and leaf compartments. Almost all nutrients presented cycling times greater than the value found for the renewal of their respective (stem and leaf) compartment (table VI). This fact suggested that nutrient translocation occurred before abscission, a mechanism that may play an important nutrient conservation role. In this way, elements are kept out of the more open phase of nutrient cycling (litterfall, decomposition and soil processes), where their loss is easier. In tropical, rainy regions, the soil is often nutrient-poor, and such conservation strategies are very important for ecosystem establishment and stability $[31,35]$.

Comparing our data with those for other ecosystems (tables VII and VIII), we could verify many differences,
Table VI. Nutrient dynamics in the gallery forest compartments, Itapira, SP, Brazil.

\begin{tabular}{lcccccc}
\hline & $\begin{array}{c}\text { Total aboveground } \\
\text { biomass } \\
\left(\mathrm{g} \mathrm{ha}^{-1}\right)\end{array}$ & \multicolumn{2}{c}{$\begin{array}{c}\text { Fluxes by } \\
\text { litterfall* } \\
\left(\mathrm{g} \mathrm{ha}^{-1} \mathrm{yr}^{-1}\right)\end{array}$} & $\begin{array}{c}\text { Mean cycling } \\
\text { time } \\
(\text { years })\end{array}$ \\
& Leaves & Stems & Leaves & Stems & Leaves Stems \\
\hline O.M. & 7300000 & 126100000 & 4328420 & 1604090 & 1.7 & 7.9 \\
$\mathrm{~N}$ & 227600 & 341100 & 76911.3 & 16785.9 & 7.9 & 20.3 \\
$\mathrm{P}$ & 15900 & 23300 & 3037.2 & 791.9 & 13.3 & 29.4 \\
$\mathrm{~K}$ & 92410 & 145400 & 19888.2 & 4770.1 & 18.4 & 30.5 \\
$\mathrm{Ca}$ & 87800 & 144700 & 36829.3 & 10784.5 & 6.3 & 13.4 \\
$\mathrm{Mg}$ & 28400 & 44300 & 12494.3 & 3078.9 & 7.3 & 14.4 \\
$\mathrm{~S}$ & 14900 & 22400 & 7108.8 & 998.2 & 17.3 & 22.4 \\
$\mathrm{Fe}$ & 4112 & 6516 & 2001.8 & 699.4 & 4.8 & 9.3 \\
$\mathrm{Cu}$ & 87 & 122 & 45.9 & 15.9 & 2.7 & 7.7 \\
$\mathrm{Mn}$ & 9400 & 17490 & 1805.6 & 413.3 & 19.4 & 42.3 \\
$\mathrm{~B}$ & 192 & 306 & 259.4 & 34.6 & 4.5 & 8.8 \\
\hline
\end{tabular}

* Data from (14).

Table VII. Mean nutrient concentrations $\left(\mathrm{mg} \mathrm{g}^{-1}\right)$ in different tropical forest ecosystems.

\begin{tabular}{|c|c|c|c|c|c|c|}
\hline $\begin{array}{l}\text { Ecosystem } \\
\text { Country }\end{array}$ & & $N$ & $P$ & $K$ & $\mathrm{Ca}$ & $\mathrm{Mg}$ \\
\hline Mountain rain forest & Leaves & 8.2 & 0.8 & 7.6 & 12.4 & 1.9 \\
\hline New Guinea ${ }^{(25)}$ & Stems & 2.2 & 0.1 & 2.7 & 4.6 & 0.7 \\
\hline $\begin{array}{l}\text { Moist subtropical } \\
\text { Puerto Rico }{ }^{(50)}\end{array}$ & Mean & 3.0 & 0.2 & 2.5 & 2.1 & 0.6 \\
\hline Moist tropical & Leaves & 18.8 & 1.3 & 7.6 & 19.0 & 2.6 \\
\hline Ghana $^{(24)}$ & Stems & 3.8 & 0.3 & 1.9 & 5.6 & 0.8 \\
\hline $\begin{array}{c}\text { Mountain rain forest } \\
\text { Jamaica }^{(50)}\end{array}$ & Leaves & 14.2 & 0.8 & 10.6 & 7.4 & 3.8 \\
\hline Moist tropical & Leaves & 1.6 & 15.3 & 16.8 & 3.2 & \\
\hline Panamá(23) & Stems & 1.2 & 10.4 & 9.9 & 1.3 & \\
\hline Tropical gallery (4 sites) & Leaves & 7.9 to & 0.1 to & 4.8 to & 1.1 to & 1.4 to \\
\hline DF Brazil (43) & (range) & 29.1 & 3.9 & 33.4 & 29.4 & 12.1 \\
\hline Tropical gallery & Leaves & 31.0 & 2.1 & 12.7 & 11.7 & 4.2 \\
\hline Brazil [This study] & Stems & 9.3 & 1.0 & 5.8 & 5.6 & 1.0 \\
\hline
\end{tabular}

although there are few data for generalisation. Differences in sampling and analytical methods must also be taken into account $[4,5,46]$. Even so, one may observe that this forest has greater concentrations of $N$ and $P$ than other tropical forests studied in New Guinea [25], Puerto Rico [50], Ghana [23] and Panama [53]. Nutrient concentrations found in our study were similar to those observed in four gallery forests in Central Brazil [43], but in Mogi Guaçu the nitrogen concentrations were in the upper limits found by those authors 
Table VIII. Nutrient pools $\left(\mathrm{kg} \mathrm{ha}^{-1}\right)$ in some tropical ecosystems.

\begin{tabular}{lcccccc}
\hline $\begin{array}{c}\text { Ecosystem } \\
\text { Country }\end{array}$ & $N$ & $P$ & $K$ & $\mathrm{Ca}$ & $\mathrm{Mg}$ & $S$ \\
\hline $\begin{array}{c}\text { Mountain rain forest } \\
\quad \text { New Guinea }\end{array}$ & & & & & & \\
$\begin{array}{c}\text { Moist subtropical } \\
\quad \text { Puerto Rico }^{(50)}\end{array}$ & 670 & 40 & 654 & 1361 & 195 & \\
$\begin{array}{c}\text { Moist tropical } \\
\quad \text { Ghana }^{(24)}\end{array}$ & 1832 & 126 & 820 & 2527 & 346 & \\
$\begin{array}{c}\text { Moist tropical } \\
\quad \text { Panamá(23) }\end{array}$ & & 158 & 3020 & 3894 & 402 & \\
$\begin{array}{c}\text { Savanna } \\
\quad \text { Brazil(14) }\end{array}$ & 223 & 15 & 77 & 55 & 19 & 17 \\
$\begin{array}{c}\text { Tropical gallery } \\
\text { Brazil (This study) }\end{array}$ & 1001 & 104 & 553 & 634 & 139 & 74 \\
\hline
\end{tabular}

(table VII). These greater concentrations may be due to the leaching of nutrients from neighbouring agrosytems and their subsequent accumulation by plants.

The moist subtropical forest studied in Puerto Rico [50] presented some similarities with respect to the $\mathrm{Ca}$, $\mathrm{K}$, and $\mathrm{Mg}$ stored. We did not find micronutrient storage data to compare with ours. Micronutrient inventories are rare and represent an important gap in the ecological knowledge of the tropics [12].

The Savannah (Campo Cerrado) ecosystems studied in the same region presented much smaller values for biomass (23 $\mathrm{Mg} \mathrm{ha}^{-1}$ ) and nutrient pools (table VIII). The differences verified between these adjoining ecosystems are attributed to the greater water availability in the gallery forest.

Carbon amounted to $48.4 \%$ of the plant biomass, and this value is very near the generally proposed $50 \%$ mean value $[3,4,24]$. The carbon stored in this gallery forest (64.4 $\mathrm{Mg} \mathrm{ha}^{-1}$ ) fits well with the general mean prediction for tropical forests $\left(53 \mathrm{Mg} \mathrm{ha}^{-1}\right)$ [4], because the authors considered different forests and different sucessional stages.

The greatest reservoir of Carbon and all other aboveground nutrients was the tree stem (table $V$ ). In the case of clear-cutting, the majority of nutrients are lost, as well as the biological mechanisms of nutrient filtering and accumulation. The terrestrial Carbon sink will decrease and the adjoining aquatic ecosystems are also thought to be affected by clear-cutting [21].

Our data agree with general estimates of soil organic carbon that point to a 2-to-3 times greater carbon accumulation in soils than in vegetation, and even greater amounts were found in other tropical forests [25]. The same was observed in Mediterranean forests [2], and in other types of ecosystems [45]. For this type of environment, the estimated carbon soil density was from 8 to $10 \mathrm{~kg} \mathrm{C} \mathrm{m}^{-2}$ [45]. The greater value found in this study $\left(11 \mathrm{~kg} \mathrm{C} \mathrm{m}^{-2}\right.$ ) seems to be due to a better water supply which permits organic matter accumulation. Plants established near the Mogi Guaçu River and closer to the water table were less affected by the winter decrease in rainfall. The main driving force in gallery forest ecosystems is the water flow, since it results in changes in soil properties, and allows greater plant-cover development. Vegetation subsequently affects soil dynamics through nutrient and organic matter additions, and the plant cover is consequently favoured by these changes in a positive feedback process. The system evolves to a state that is very different from the ecosystems developed in the surrounding areas.

In Brazil, gallery forests cover about 16 million hectares [29], a much smaller area than other Brazilian biomes. Because of this small area, the effect of these ecosystems on global carbon pools could be considered almost negligible. However, gallery forests may be very important at a regional scale, due to their specific environmental and conservation functions mentioned above [38]. The integrity of the landscape with respect to erosion control, biological diversity, ecological processes and gene flows is affected by the loss of such forests, which play key environmental roles [17]. The carbon and nutrient pools determined in this study must be taken into account in water reservoir constructions, because water quality may be affected by these elements [42]. Basic ecological data, such as nutrient concentrations and pools are important ecological characteristics, which should be taken in consideration in management planning, for wood exploitation, land-use changes, water quality control and restoration programs. The State of São Paulo is one of the most deforested areas in Latin America, due to agriculture (mainly coffee and sugarcane), urbanisation and other land-use changes. As a result, there is said to be a very high species and soil erosion rate. For this reason, gallery forests, and the other remaining natural ecosystems must be protected and restored for their important ecological functions.

Acknowledgements: This study was supported by FAPESP, Fundação de Amparo à Pesquisa do Estado de S. Paulo, grant No. 94/2722. The second author received a grant from CAPES. We thank V. Ramón Vallejo, Juli Pausas and Anna Ferran (University of Barcelona and CEAM) for their valuable comments on an early draft of this manuscript. Jacqueline Scheiding provided the linguistic correction. We are indebted to Paulo César Fernandes and Marcos Batalha for their collaboration in the data collection. W. Delitti also thanks his colleagues 
on the CEAM team and the people of València for their marvellous hospitality.

\section{REFERENCES}

[1] Barbosa L.M., Simpósio sobre matas ciliares, São Paulo, Cargill, Campinas, 1989.

[2] Bottner P., Couteaux M.M., Vallejo V.R., Soil organic matter in Mediterranean-type ecosystems and global climatic Changes: A case study - The soils of the Mediterranean Basin. In Global change and Mediterranean-type ecosystems, Moreno J.J., Oechel W.C. (Eds.), Springer-Verlag, New York, 1995, pp. 306-325.

[3] Brown S., Lugo A.E., The storage and production of organic matter in tropical forests and their role in the global carbon cycle, Biotropica 14 (3) (1982) 161-87.

[4] Biomass of tropical forests: A new estimate based on forest volumes, Science 223 (3) (1984) 1290-1293.

[5] Bruijnzeel L.A., Nutrient input - output budgets of tropical forest ecosystems: A review. J. Trop. Ecol. 7 (1991) 1-24.

[6] Burger D.M., Fitomassa e mineralomassa da mata ciliar do rio Mogi Guaçu, Itapira - SP. MS Thesis. Instituto de Biociências, Univ São Paulo, 1997.

[7] Burger D.M., Delitti W.B.C., 1997 Above ground phytomass of the gallery forest of the Mogi-Guaçu river (Itapira, São Paulo, Brazil) in: Imaña-Encinas J., Klein C. (Eds.) Proceedings International Symposium on Assessment and Monitoring of Forests in tropical Dry Regions with Special Reference to Gallery Forests, Brasília, pp. 231-238.

[8] César O., Composição florística, fitossociologia e ciclagem de nutrientes em mata mesófila semidecídua (Fazenda Barreiro Rico, mun. Anhembi - SP). Rio Claro, Thesis, Instituto de Biociências, UNESP, 1988.

[9] CESP-Companhia Energética de São Paulo, Engecorps Aproveitamento múltiplo do Rio Mogi-Guaçu, PCH-MogiGuaçu, Consolidação do Projeto Básico. Estudo Ambiental, São Paulo, 1993.

[10] Chapin F.S., Effects of multiple environment stresses on nutrient availability and use. In: Mooney H.A., Winner W.E. and Pell E.J. (Eds.) Response of plants to multiple stresses, Academic Press, San Diego, 1991.

[11] Couto W., Sanzonowics C., Leite G.G., Effect of excess water in an oxisol on ammonium, nitrate, iron, and manganese availability and nutrient uptake of two tropical forage species, Plant Soil 73 (1983) 159-66.

[12] David-Brain E., Deficiencies and toxicities of trace elements and micronutrients in tropical soil: Limitations of knowledgements and future research needs, Environ Toxic. Chem. 16 (1) (1997) 75-83.

[13] Delitti W.B.C., Estudos de ciclagem de nutrientes: Instrumentos para a análise funcional de ecossistemas terrestres, Oecol. Brasil. 1 (1995) 469-486.

[14] Delitti W.B.C., Ciclagem de nutrientes em cerrados. VIII Seminário Regional de Ecologia, UFSCar, São Carlos, 1997, 1031-1045.
[15] De Vuono Y.S., Batista E.A., Funari F.L., Balanço hídrico na área da Reserva Biológica de Mogi-Guaçu, São Paulo-Brasil. Hoenea 13 (1986) 73-85.

[16] Duvigneaud P., La synthèse écologique, Paris, Doin (Ed.), 1974.

[17] Dvorak J., Novak L., Soil Conservation and Silviculture, Develop. Soil Science 23, Elsevier, Prague, 1994.

[18] Empresa Brasileira de Pesquisa Agropecuária Manual de métodos de análise de solo, Serviço Nacional de Levantamento e Conservação dos Solos, Rio de Janeiro, 1979.

[19] Ethirington J.R., Environment and plant ecology, John Wiley \& Sons, London, 1975.

[20] Fitter A.H., Hay R.K.M., Environmental physiology of plants, Academic Press, San Diego, 1987.

[21] France R., Culbert H., Peters R., Decreased Carbon and nutrient input to Boreal lakes from particulated organic matter following riparian clear-cutting, Environ. Manag. 20 (4) (1996) 579-583.

[22] Golley F.B., Mcginnis J.T., Clements R.G., Child G.I., Duever M.J., Ciclagem de minerais em um ecossistema de floresta tropical úmida, São Paulo: EDUSP, 1978.

[23] Greenland D.J., Kowal J.M.L., Nutrient content of the moist tropical forest of Ghana, Plant Soil 12 (2) (1960) 154-74.

[24] Grierson P.F., Adams M.A., Attiwill P.M., Estimates of carbon storage in the above-ground biomass of Victoria's forests, Aust. J. Bot. 40 (4,5) (1992) 631-40.

[25] Grubb P.J., Edwards P.J., Studies of mineral cycling in a montane rain forest in New Guinea. II - The distribution of mineral elements in the above-ground material, J. Ecol. 70 (1982) 623-48.

[26] Haridasam M., Silva Jr. M., Felfini J.M., Rezende A.V., Silva P.E.N., Gradient analysis of soil properties and phytosociological parameters of some gallery forests on the "Chapada dos Viadeiros" in the Cerrado region of central Brazil. In Proceedings International Symposium on Assessment and Monitoring of Forests in tropical Dry Regions with Special Reference to Gallery Forests, Imaña-Encinas, J. Klein C. (Eds.), UnB, Brasília, 1997, pp. 259-276.

[27] Henry R., Vueda V.S., Afonso A., Kituchi R.M., Input of allochtonous matter and structure of fauna in a Brazilian headstream. Verhandlungen der internationalen Vereinigung fur theoretishe und angewandte limnologie 25 (1994) 1866-70.

[28] Herrera R., Jordan C.F., Klinge H., Medina E., Amazon ecosystems. Their structure and functioning with particular emphasis on nutrients, Interciência 3 (4) (1997) 223 -31.

[29] Imaña-Encinas J., Klein C., Proceedings International Symposium on Assessment and Monitoring of Forests in tropical Dry Regions with Special Reference to Gallery Forests. Brasília, 1997.

[30] Imaña-Encinas J., Paula J.E., Woo J., Survey of the Capão Comprido gallery forest, Brazil. In Proceedings International Symposium on Assessment and Monitoring of Forests in tropical Dry Regions with Special Reference to Gallery Forests, Imaña-Encinas J., Klein C. (Eds.), UnB, Brasília, 1997, pp. 191-198. 
[31] Jordan C.F., Nutrient cycling in tropical forest ecosystems. John Wiley \& Sons Ltd., Chichester, 1985.

[32] Jordan C.F., Herrera R., Tropical rain forests: are nutrients really critical? Am. Nat. 117 (2) (1981) 167-80.

[33] Jorgensen S.S., 1977 Some methods used for routine Chemical analysis, Laboratory manual, CENA, Piracicaba, Brazil, p. 22.

[34] Krug F.J., Bergamin Filho H., Zagatto E.A.G., Jorgensen S.S., 1977 Rapid determination of sulphate in natural waters and plant digests by continuous flow injection Turbidimetry, Analyst. 102, 503-508.

[35] Lange O.L., Nobel P.S., Osmond C.B., Zeigler H., Physiological plant ecology, Springer-Verlag, New York, 1982.

[36] Leitão Filho H.F., Azevedo D.B., Santin D.A., Gardolinski P.C.F.C., Relatório das atividades desenvolvidas no projeto "Estudos da mata ciliar dos Rios Mogi-Guaçu e Peixe, UHE Mogi-Guaçu - SP. Pq. Ecológico, FUNDETE e CESP, São Paulo, 1994.

[37] Lindsay Y.W.L., Norvell W.R., Development of a DTPA soil test for $\mathrm{Zn}, \mathrm{Fe}, \mathrm{Mn}$ and $\mathrm{Cu}$, Soil Sci. Soc. Amer. J. 42 (1978) 421-428.

[38] Lund H.D., A primer on designing Arid land and gallery forests resource inventories. In Proceedings International Symposium on Assessment and Monitoring of Forests in tropical Dry Regions with Special Reference to Gallery Forests, Imaña-Encinas J., Klein C. (Eds.), UnB, Brasília, 1997, pp. 23-38.

[39] Mantovani W., Conceitos e fatores condicionantes. In: Barbosa L.M. (Ed.) Simpósio sobre matas ciliares, São Paulo. Cargill, Campinas, 1989, pp. 11-19.

[40] Marschner H., 1995, Mineral nutrition of higher plants. Academic Press, p. 889.

[41] Meguro M., Vinueza G.N., Delitti W.B.C., Ciclagem de nutrientes minerais na mata mesófila secundária - São Paulo. I - Produção e conteúdo de nutrientes minerais no folhedo, Bolm. Bot. USP 7 (1979) 11-31.

[42] Mouchet P.C., Influence of recently drowned terrestrial vegetation on the quality of water stored in impounding reservoirs. Verh. Internt. Verein. Limnol. 22 (1984) 1608-1619.

[43] Nogueira P.E., Haridasan M., Foliar nutrient concentration of tree species of four gallery forests in central Brazil. In Proceedings International Symposium on Assessment and Monitoring of Forests in tropical Dry Regions with Special Reference to Gallery Forests, Imaña-Encinas J., Klein C. (Eds.), UnB, Brasília, 1997, pp. 309-322.

[44] Oliveira J.B., Menk J.R.F., Barbieri J.L., Rotta C.L., Tremocoldi W., Levantamento pedológico semi-detalhado do
Estado de São Paulo: Quadrícula de Araras. Bol. Téc. Inst. Agron. Campinas 71 (1982) 88-94.

[45] Post W.M., Emanuel W.R., Zinke P.J., Stangenberger A.G., Soil carbon pools and world life zones, Nature 298 (1982) 156-159.

[46] Proctor J., Mineral nutrient in tropical forests, Phys. Geogr. 7 (3) (1983) 422-31.

[47] Proctor J., Mineral nutrients in tropical forest and savanna ecosystems, Blackwell, 1989.

[48] Raij B., Van Quaggio J.A., Métodos de análises de solos para fins de fertilidade, Bol. Téc. IAC 81 (1981) 1-30.

[49] Rochow J.J., Estimates of above-ground biomass and primary productivity in a Missouri Forest. J. Ecol. 62 (2) (1974) 567-77.

[50] Scatena F.N., Silver W., Siccama T., Johnson A., Sánchez M.J., Biomass and nutrient content of the Bisley Experimental Watersheds, Luquillo Experimental Forest, Puerto Rico, before and after Hurricane Hugo, 1989. Biotropica 25 (1) (1993) 15-27.

[51] Silva Jr. M.C., Relationship between the tree communities of the Pitoco, Monjolo and Taquara Gallery forests and environmental factors. In Proceedings International Symposium on Assessment and Monitoring of Forests in tropical Dry Regions with Special Reference to Gallery Forests, Imaña-Encinas J., Klein C. (Eds.), UnB, Brasília, 1997, pp. 287-298.

[52] Swift M.F., Heal O.W., Anderson J.M., Decomposition in terrestrial ecosystems. Blackwell, Oxford, 1979.

[53] Tanner E.V.G., Four montane rain forest of Jamaica: a quantitative characterization of the floristics, the soils and the foliar mineral levels, and a discussion of the interrelations, J. Ecol. 65 (1977) 883-918.

[54] Vallejo V.R., Evaluation of C:N ratio as a parameter of $\mathrm{N}$ mineralization. Mitt. d. Österr. Bodenkundlichen Gesellschaff, 47 (1993) 71-78.

[55] Walter H., Harnickell E., Mueller-Dumbois D., Climate diagram maps. Springer-Verlag, Berlin, 1975.

[56] Woodwell G.M., Whittaker R.H., Hougton R.A., Nutrient concentrations in plants in the Brookhaven oak-pine forest, Ecology 56 (1975) 318-332.

[57] Zagatto E.A.G., Krug F.J., Bergamin Filho H., Jorgensen S.S., Reis B.F., Merging zones in flow injection analysis. Part 2. Determination of $\mathrm{Ca}, \mathrm{Mg}$ and $\mathrm{K}$ in plant material by continuous flow injection - Atomic absorption and flame emission spectrometry, Anal. Chem. Acta. 104 (1979) 279-284.

[58] Zagatto E.A.G., Jacintho A.O., Reis B.F., Krug F.J., Bergamin Fo.H, Pessenda L.C.R., Mortatti J., Giné M.F., Manual de análises de plantas e águas empregando sistemas de injeção em fluxo, Piracicaba: CENA-USP, 1981. 